\title{
Sick sinus syndrome
}

\section{Symptomatic cases in children}

\author{
DOROTHY J. RADFORD and T. IZUKAWA \\ From the Department of Paediatrics, Division of Cardiology, Hospital for Sick Children, Toronto, Canada
}

\begin{abstract}
Radford, D. J., and Izukawa, T. (1975). Archives of Disease in Childhood, 50, 879. Sick sinus syndrome: symptomatic cases in children. In 20 children needing treatment for symptomatic sick sinus syndrome, the average age at presentation was $7 \cdot 1$ years and ranged from 9 months to 18 years. Symptoms were never precise but, in retrospect, 5 children had syncope, 7 had a rapid heart action, 6 had dyspnoea or tachypnoea, 2 had nonspecific chest pains, 2 had pale spells, and 1 had a sudden hemiplegia. Symptoms followed cardiac surgery in 15 cases and were related to unoperated congenital heart disease in 2 and to myocarditis in 2 . The aetiology was unknown in 1 case. The type of cardiac surgery resulting in the development of the sick sinus syndrome was predominantly related to atrial suturing.

Both tachy- and bradydysrhythmias were found, including wandering atrial pacemaker ( 9 cases), junctional rhythm (19 cases), supraventricular tachycardia ( 9 cases), atrial flutter (11 cases), and atrial fibrillation ( 2 cases). Both atrial (8 cases) and ventricular ( 7 cases) premature beats were seen.

All patients were given trials of drug therapy but difficulties were encountered. Cardioversion was used for tachyarrhythmias in 11 cases without serious problems. Six children had permanent cardiac pacemakers inserted with good results. Recognition of the sick sinus syndrome in childhood is important and treatment must be regulated by the severity of symptoms.
\end{abstract}

More interest in the sick sinus syndrome has been shown recently and it has been recognized more often (Ferrer, 1973; Kaplan et al., 1973; Lloyd-Mostyn, Kidner, and Oram, 1973; Moss and Davis, 1974; Rubenstein et al., 1972; Radford and Julian, 1974). The condition presents a wide spectrum of clinical manifestations and of problems with management. Most reports have been of adult patients, mostly elderly, and recordings of cases in children are few (Nugent et al., 1974; Scott and Macartney, 1974; Greenwood, et al., 1974). However, the condition occurs in children and its recognition and treatment are important.

Lown (1967) defined the sick sinus syndrome as a defect in elaboration or conduction of sinus impulses characterized by chaotic atrial activity, changing $\mathrm{P}$-wave contour, and bradycardia interspersed with multiple and recurrent ectopic beats and runs of atrial and nodal tachycardia. The diagnosis is

Received 12 March 1975. essentially an electrocardiographic one. Using Easley and Goldstein's (1971) subclassification, type I sick sinus syndrome is diagnosed in patients exhibiting inappropriate sinus bradycardia or sinus arrest, and type II in those showing a bradycardiatachycardia combination. We present here 20 cases of the sick sinus syndrome in children who had symptoms associated with their dysrhythmias and who have required treatment.

\section{Patients and methods}

A computer write-out of coded arrhythmias in children seen in the Cardiology Department of the Hospital for Sick Children, Toronto, was obtained and the electrocardiograms (ECG) and case records of the patients surveyed. Sequential ECGs of all patients at the hospital who had had the Mustard operation (Mustard et al., 1964) of an intra-atrial baffle for transposition of the great vessels were also reviewed and the dysrhythmias documented (Mulholland et al., 1975). Those with atrial arrhythmias occurring only in the immediate postoperative period were excluded 
as also were children who had isolated atrial dysrhythmias without symptoms. The remaining 20 patients who had ECG evidence of the sick sinus syndrome and symptoms needing therapy were reviewed.

\section{Results}

Clinical details of the 20 patients (13 boys, 7 girls) are shown in Table $\mathrm{I}$. Their mean age at onset of symptoms was $7 \cdot 1$ years with a range of 9 months to 18 years. Three had bradyarrhythmias alone (type I sick sinus syndrome) and the other 17 had symptomatic brady-tachycardia (type II).

Symptoms. Although the symptoms were often imprecise at the time, in retrospect they can be summarized as follows: 5 children had

TABLE I

Clinical data of 20 children with sick sinus syndrome (SSS)

\begin{tabular}{|c|c|c|c|c|c|c|c|c|c|c|}
\hline \multirow[t]{2}{*}{$\begin{array}{l}\text { Case } \\
\text { no. }\end{array}$} & \multirow[t]{2}{*}{ Sex } & \multirow{2}{*}{$\begin{array}{c}\text { Age } \\
\text { at } \\
\text { onset } \\
\text { (years) }\end{array}$} & \multirow[t]{2}{*}{ Symptoms } & \multirow[t]{2}{*}{$\begin{array}{l}\text { Associated } \\
\text { conditions }\end{array}$} & \multirow[t]{2}{*}{$\begin{array}{l}\text { Cardiac } \\
\text { surgery }\end{array}$} & \multirow{2}{*}{$\begin{array}{c}\text { Time } \\
\text { relation } \\
\text { of } \\
\text { symptoms } \\
\text { to } \\
\text { surgery }\end{array}$} & \multirow[t]{2}{*}{$\begin{array}{l}\text { Type } \\
\text { of } \\
\text { sss }\end{array}$} & \multicolumn{3}{|c|}{ Treatment } \\
\hline & & & & & & & & Drugs & Cardioversion & Pacemaker \\
\hline 1 & $\mathbf{M}$ & 7 & $\begin{array}{l}\text { Syncope, } \\
\text { dizziness }\end{array}$ & $\begin{array}{l}\text { Normal heart } \\
\text { (catheter study) }\end{array}$ & - & - & I & + & - & + \\
\hline 2 & $\mathbf{M}$ & 13 & $\begin{array}{l}\text { Palpitations } \\
\text { dizziness }\end{array}$ & $\begin{array}{l}\text { Normal heart } \\
\text { (clinically) }\end{array}$ & - & - & II & + & + & - \\
\hline 3 & F & 4 & $\begin{array}{l}\text { Dyspnoea } \\
\text { (conges- } \\
\text { tive heart } \\
\text { failure) }\end{array}$ & $\begin{array}{l}\text { Coxsackie } \\
\text { viral } \\
\text { myocarditis }\end{array}$ & - & - & II & + & - & - \\
\hline 4 & F & 5 & $\begin{array}{l}\text { Mother noted } \\
\text { rapid } \\
\text { heart }\end{array}$ & Secundum ASD & + & Pre-op & II & + & - & - \\
\hline 5 & $\mathbf{M}$ & 14 & $\begin{array}{l}\text { Syncope, } \\
\text { chest pain }\end{array}$ & Primum ASD & + & 7 years & I & + & - & + \\
\hline 6 & $\mathbf{M}$ & 12 & $\begin{array}{l}\text { Syncope, } \\
\text { dizziness, } \\
\text { palpita- } \\
\text { tions }\end{array}$ & $\begin{array}{l}\text { Sinus venosus } \\
\text { ASD with } \\
\text { PAPVD }\end{array}$ & + & 8 years & II & + & - & + \\
\hline 7 & $\mathbf{M}$ & 9 & $\begin{array}{l}\text { Brief chest } \\
\text { pains }\end{array}$ & $\begin{array}{c}\text { Sinus venosus } \\
\text { ASD with } \\
\text { PAPVD }\end{array}$ & + & 2 years & II & + & + & - \\
\hline 8 & F & 12 & $\begin{array}{r}\text { Palpitations } \\
\text { dyspnoea }\end{array}$ & $\begin{array}{l}\text { Common atrium } \\
\text { with PAPVD }\end{array}$ & + & $\begin{array}{l}\text { Immediate } \\
\text { postop }\end{array}$ & II & + & + & - \\
\hline 9 & $\mathbf{M}$ & 5 & Palpitations & TAPVD & + & 2 years & II & + & + & - \\
\hline 10 & $M$ & 9 & $\begin{array}{l}\text { Palpitations, } \\
\text { weakness }\end{array}$ & $\begin{array}{l}\mathrm{T} \text { of } \mathrm{F} \text { with left } \\
\text { SVC draining } \\
\text { to coronary } \\
\text { sinus }\end{array}$ & + & 1 year & II & + & + & - \\
\hline 11 & $\mathbf{M}$ & 18 & Syncope & $\begin{array}{l}\mathbf{T} \text { of } \mathbf{F} \text { with } \\
\text { pulmonary } \\
\text { cusp agenesis }\end{array}$ & + & 11 years & I & + & - & + \\
\hline 12 & F & 11 & Syncope & $\begin{array}{c}\text { Single ventricle } \\
\text { pulmonary } \\
\text { atresia, PDA }\end{array}$ & - & - & II & + & - & + \\
\hline 13 & $\mathbf{F}$ & 3 & Tachypnoea & $\begin{array}{l}\text { Single ventricle } \\
\text { with TGA } \\
\text { double orifice } \\
\text { tricuspid }\end{array}$ & + & 2 years & II & + & + & - \\
\hline 14 & F & 5 & $\begin{array}{c}\text { Dyspnoea } \\
\text { (cardiac } \\
\text { failure) }\end{array}$ & $\begin{array}{l}\text { Double outlet } \\
\text { RV with TGA }\end{array}$ & + & 4 years & II & + & - & + \\
\hline 15 & $\mathbf{F}$ & $9 / 12$ & Hemiplegia & TGA & + & $8 / 12$ & II & + & - & - \\
\hline 16 & $\mathbf{M}$ & $17 ! 12$ & $\begin{array}{l}\text { Pale spells, } \\
\text { dyspnoea }\end{array}$ & TGA & + & $3 / 12$ & II & + & + & - \\
\hline 17 & $M$ & 3 & Pale spells & TGA & + & 2 years & II & + & + & - \\
\hline 18 & $\mathbf{M}$ & 3 & $\begin{array}{l}\text { Rapid heart } \\
\text { action, } \\
\text { dyspnoea }\end{array}$ & TGA & + & $1 / 12$ & II & + & + & - \\
\hline 19 & $\mathbf{M}$ & 4 & Dyspnoea & TGA & + & $\begin{array}{l}\text { Immediate } \\
\text { postop }\end{array}$ & II & + & + & - \\
\hline 20 & $\mathbf{M}$ & 4 & Palpitations & TGA & + & $5 / 12$ & II & + & + & - \\
\hline
\end{tabular}

ASD, atrial septal defect; PAPVD, partial anomalous pulmonary venous drainage; TAPVD, total anomalous pulmonary venous drainage; $T$ of F, tetralogy of Fallot; TGA, transposition of great arteries; RV, right ventricle. 
syncope, 7 had palpitations or rapid heart actions recognized either by the children or parents, 6 had dyspnoea or tachypnoea or congestive cardiac failure (not necessarily entirely related to the dysrhythmias, since there were associated cardiac lesions), 2 had nonspecific chest pains which were not typically anginal, 2 young children were observed by parents to have 'pale spells,' and 1 infant presented with a sudden left hemiplegia clinically attributed to a cerebral embolus.

Associated conditions. Associated cardiac defects were investigated by cardiac catheterization in 18 cases. Of the two patients not investigated one had a clinically normal heart and the other had coxsackie myocarditis proved by viral studies. The catheter study brought on supraventricular tachycardia in two cases and bradyarrhythmias in three. Five children showed signs of the sick sinus syndrome without having had any preceding cardiac surgery. Two of these had congenital heart defects (one with a large ostium secundum atrial septal defect, which has since been repaired, and one with a single ventricle, transposed position of the great arteries, and a double orifice tricuspid valve). The other three had no known anatomical abnormalities, but one had proved viral myocarditis and a similar pathological process was suspected in another on the basis of abnormal $\mathrm{T}$-wave inversions in the ECG. Symptoms in the other 15 patients followed cardiac surgery, their onset ranging from the immediate postoperative period (Cases 8 and 19) to 11 years after surgery (Case 11).

Surgery. The type of cardiac surgery resulting in the development of the sick sinus syndrome was almost entirely related to manipulation and suturing of the atrial chambers. The three patients with atrial septal defects and the one with a common atrium had had patch reconstructions of the atrial septum. The boy with total anomalous pulmonary venous drainage into the left superior vena cava had had surgical implantation of the anomalous common venous chamber into the left atrium. The patient with a single ventricle and transposed relationship of the great vessels had had a surgical creation of an atrial septal defect (Blalock and Hanlon, 1950). Seven children with transposition of the great arteries had had redirection of the venous return by the insertion of an intra-atrial baffle (Mustard et al., 1964). In only one patient was the Mustard operation the primary surgery and the other six had had previous palliative operation. Two of the six had had preceding Blalock-Hanlon atrial septectomies and four had had the operation described by Edwards and Bargeron (1965), of creating partial anomalous venous return into the right atrium by moving the atrial septum. The patient who developed a hemiplegia did so 8 months after her Sterling Edwards operation and before the Mustard repair.

The two patients with tetralogy of Fallot had had total correction operations with patch closure of the ventricular septal defect and infundibulectomy. The associated abnormality of a left superior vena cava draining into the coronary sinus had been left untreated in Case 10. One patient (Case 11) had had more complicated surgery four years after the initial repair, as he had required a further infundibulectomy and replacemnt of the pulmonary valve (which had cusp agenesis) with a homograft valve. A third operation was necessary to replace the homograft valve (which calcified) with a prosthetic valve.

Electrocardiograms. The ECG features of the 20 children are shown in Table II: and the fastest and slowest heart rates recorded are given. Atrial flutter was more common then atrial fibrillation, which occurred in only two cases. Ventricular ectopic beats were recorded in 7 patients, two of whom had documented ventricular tachycardia. Illustrative examples of the various rhythms in one patient (Case 8) are shown in the Fig.

Treatment. All patients were given trials of drug therapy. The most widely used drug was digoxin, which was given to 16 patients, often for its inotropic action as well as for its chronotropic action. The other often used antiarrhythmic drug was propanolol. Eight patients who had symptomatic tachycardia were treated with combined digoxin and propanolol, but when bradycardia occurred this had to be stopped. Case 2 had a total of 8 different antiarrhythmic drugs prescribed in varying combinations (over several years) in an attempt to control his episodic tachycardia. The sympton of dizziness due to bradycardia in Case 1 improved with ephedrine, but the patient developed syncope and a permanent pacemaker was inserted. Two other patients with syncope were given sustained-action tablets of isoprenaline hydrochloride (Saventrine) while under close observation as inpatients. However, the drug caused supraventricular tachycardia in one and a short run of self-terminating ventricular fibrillation in the other and was withdrawn. Both patients had a permanent pacemaker inserted. 
TABLE II

Electrocardiographic features in 20 children with sick sinus syndrome

\begin{tabular}{|c|c|c|c|c|c|c|c|c|c|}
\hline \multirow[b]{2}{*}{$\begin{array}{l}\text { Case } \\
\text { no. }\end{array}$} & \multicolumn{5}{|c|}{ Rhythms (with slowest or fastest rate recorded) } & \multicolumn{2}{|c|}{ Ectopics } & \multirow[b]{2}{*}{$\begin{array}{l}\text { QRS } \\
\text { axis }\end{array}$} & \multirow[b]{2}{*}{$\begin{array}{l}\text { Other } \\
\text { features }\end{array}$} \\
\hline & $\begin{array}{l}\text { Sinus } \\
\text { rhythm }\end{array}$ & $\begin{array}{l}\text { Wandering } \\
\text { atrial } \\
\text { pacemaker }\end{array}$ & $\begin{array}{l}\text { Junctional } \\
\text { rhythm }\end{array}$ & $\begin{array}{l}\text { Supra- } \\
\text { ventricular } \\
\text { tachycardia }\end{array}$ & $\begin{array}{l}\text { Atrial } \\
\text { flutter }\end{array}$ & Atrial & Ventricular & & \\
\hline 1 & $+(40)$ & - & + & - & - & - & + & $-30^{\circ}$ & Nil \\
\hline 2 & $+(30)$ & - & - & - & - & - & + & $0^{\circ}$ & $\begin{array}{l}\text { VT Deep } T \text { wave } \\
\text { inversion in } \\
V_{1}-V_{4}\end{array}$ \\
\hline 3 & $+(60)$ & + & + & $+(170)$ & $\cdots$ & & - & +60 & $\begin{array}{c}\text { Inverted } T \text { waves } \\
V_{1}-V_{6}\end{array}$ \\
\hline 4 & + & - & + & - & $+(145)$ & - & - & +120 & RVH \\
\hline 5 & + & - & $+(12)$ & - & - & + & + & $-75^{\circ}$ & RBBB LVH \\
\hline 6 & + & - & $+(20)$ & - & + & + & - & $+60^{\circ}$ & RSR RVH LVH \\
\hline 7 & + & - & + & - & $+(140)$ & - & - & +100 & RSR RVH \\
\hline 8 & + & + & $+(36)$ & $+(220)$ & + A Fib & + & + & +60 & - \\
\hline 9 & & + & $+(60)$ & - & $+(150)$ & + & - & +75 & RSR LVH \\
\hline 10 & $+(46)$ & - & $+(50)$ & $+(200)$ & - & - & - & +140 & RSR RVH \\
\hline 12 & + & + & + & + & $\ldots$ & + & + & +30 & LVH RVH \\
\hline 13 & + & - & $+(60)$ & $+(280)$ & + & + & - & $-15^{\circ}$ & LVH \\
\hline 14 & + & + & $+(55)$ & $+(150)$ & - & + & - & +150 & RBBB \\
\hline 15 & - & + & $+(55)$ & $+(240)$ & A Fib (170) & - & - & +120 & RVH \\
\hline 16 & + & + & $+(64)$ & - & $+(150)$ & - & - & +165 & RVH \\
\hline 17 & + & - & $+(65)$ & $\cdots$ & $+(150)$ & - & + & +135 & RVH \\
\hline 18 & & - & $+(72)$ & - & $+(150)$ & + & - & +135 & RVH \\
\hline 19 & $+(45)$ & - & + & $+(260)$ & + & .. & + & +140 & $\begin{array}{l}\text { Short run of VT } \\
\text { RVH }\end{array}$ \\
\hline 20 & + & + & $+(43)$ & $+(180)$ & $+(150)$ & - & - & +165 & RBBB \\
\hline
\end{tabular}

A Fib, atrial fibrillation; VT, ventricular tachycardia; RVH, right ventricular hypertrophy; LVH, left ventricular hypertrophy; RBBB, right bundle branch block; RSR, RSR pattern of QRS complex.

Cardioversion was performed in 11 of the patients on 1 to 7 different occasions. No serious problems such as embolism or collapse were recorded, though sinus rhythm was not always restored.

Pacemakers. Permanent cardiac pacemakers were inserted in 6 patients. Five of these had syncope and the sixth had severe cardiac failure worsened by episodic tachyarrhythmia. Of those with syncope three had type I sick sinus syndrome with bradycardia only. The other two had both bradycardia and tachycardia, but after the pacemaker was inserted they had no further palpitations and required no drugs. The sixth patient had only recently had a further cardiac operation to relieve a left ventricular outflow obstruction and to repair the mitral valve, and the permanent pacemaker was inserted to help to control her longstanding dysrhythmias.

One patient was given an atrial epicardial fixed rate (asynchronous type) pacemaker. The others were given ventricular synchronous (demand) systems, of which two have transvenous electrodes and three have electrodes sutured to the epicardium.

His-bundle studies were attempted in four of the pacemaker patients. Adequate recordings could not to be obtained in one and in another the conduction intervals accorded with the normal values of Abella et al. (1972). In the other two intra-atrial conduction was prolonged by $50 \%$ and $100 \%$ respectively and the $\mathrm{H}-\mathrm{V}$ interval (Hisbundle to ventricular depolarization time) was also prolonged by $5 \%$ and $15 \%$. In a fifth patient atrial pacing showed a 2:1 atrioventricular block at rates of 130 to $150 /$ minute.

\section{Discussion}

The many previous reports of the sick sinus syndrome have been of the condition in adults mostly elderly and with ischaemic heart disease as the commonest aetiological factor (Radford and Julian, 1974; Chokshi et al., 1973). Recognition of the syndrome in children is recent and important (Nugent et al., 1974; Scott and Macartney, 1974; Greenwood et al., 1974).

Most of our symptomatic cases followed cardiac surgery. This is of particular interest because of the increase in cardiac surgery in childhood and the reported development later of arrhythmias. Varying atrial dysrhythmias of the sick sinus syndrome after surgical closure of atrial septal defects (Young, 


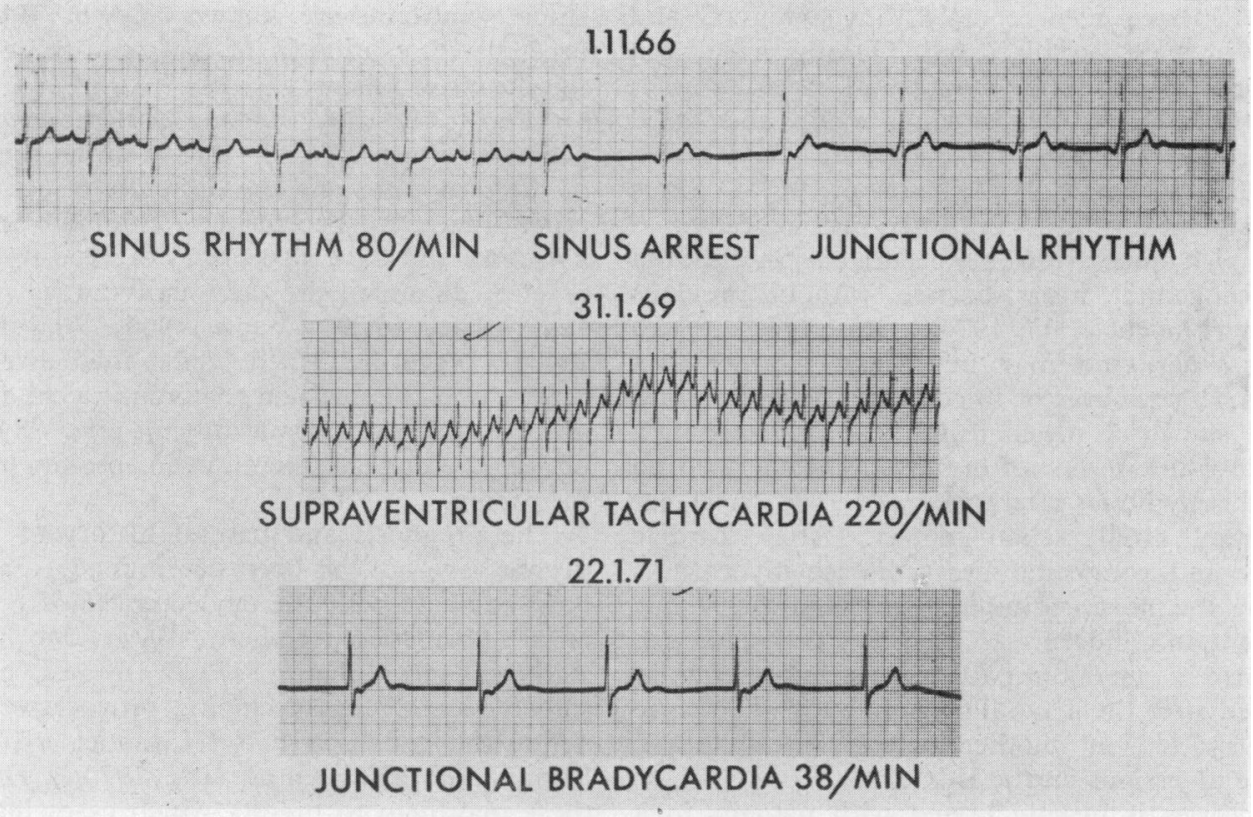

\subsubsection{9}

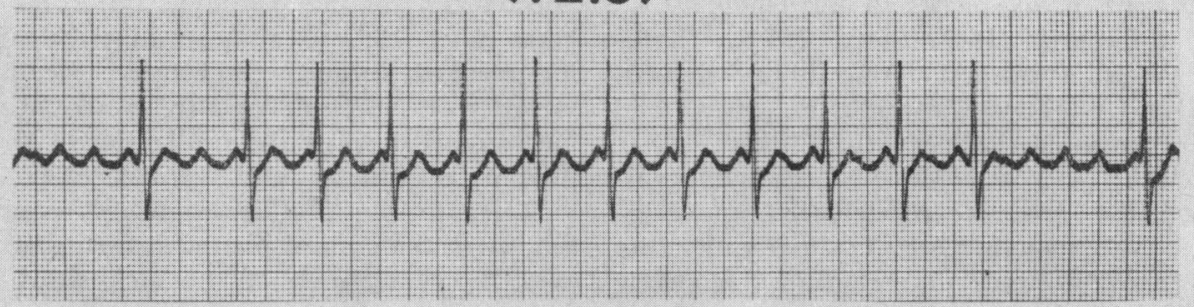

ATRIAL FLUTTER WITH VARYING BLOCK

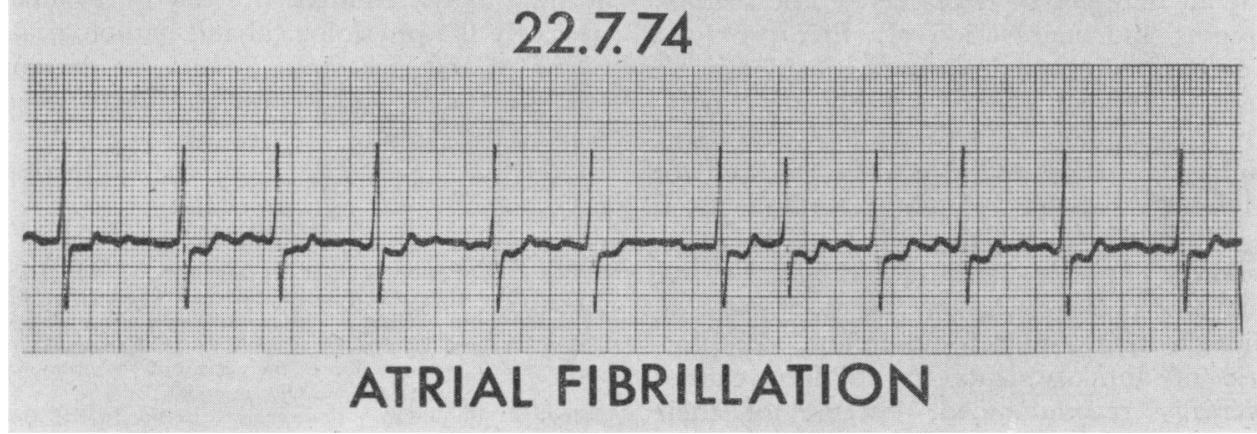

Fig.-Case 8. Illustrative examples of the various sick sinus syndrome rhythms (lead II) over a period of 8 years. 
1973) and after the Mustard operation (El-Said et al., 1972) have been reported, but symptoms and treatment were not discussed. Deaths have been attributed to the dysrhythmias and careful studies have been made of the sinus node and atrial myocardium (Kaplan et al., 1973; El-Said et al., 1972; Isaacson et al., 1972; Hudson, 1967). Sinus node damage has been confirmed histologically.

The sick sinus syndrome occurs also in children with congenital heart disease without previous surgery (Nugent et al., 1974). It occurred in two of our cases, and may be related to increased intra-atrial pressures or to congenital abnormalities of the sinoatrial mechanisms. The former was more probable in one of our children, who had no more dysrhythmias after surgical correction of her secundum atrial septal defect. After cardiac surgery and congenital heart disease myocarditis may be the next commonest cause of sick sinus syndrome in children. Coxsackie myocarditis was confirmed in one of our patients, whose arrhythmias persisted after the acute illness, and a similar cause was suspected in another because of abnormal $\mathrm{T}$-wave inversions on the ECG.

Our series is heavily biased with patients in a cardiology department and cases of the sick sinus syndrome in childhood may cover a wider field. Other related conditions described in adults are rheumatic heart disease (Rokseth and Hatle, 1974), previous diphtheria (Rasmussen, 1971), thyrotoxicosis (Wan, Lee, and Toh, 1972), familial rhythm disorder (Lloyd-Mostyn et al., 1973), and dystrophia myotonia (Radford, and Julian, 1974). The variability and vagueness of the symptoms make diagnosis difficult (particularly in young children). Also a single electrocardiogram rhythm strip may show normal sinus rhythm. A strong clinical suspicion is needed and then arrhythmia monitoring may be indicated (Crook et al., 1973).

Treatment may not be necessary. The severity of symptoms and aggravation of other problems such as cardiac failure are important considerations. Treatment is difficult. Any therapy for bradycardias may precipitate tachycardia and vice versa. The troublesome rhythms have to be assessed for the individual patient. Cerebral emboli from changing rhythms have been reported in adults (Rubenstein et al., 1972; Radford and Julian 1974). One such case occurred in our series, presenting as hemiplegia in a 9-month-old infant. Prophylactic use of anticoagulants in children cannot be universally recommended, because of their inherent dangers and because the incidence of emboli in children with this condition is as yet unknown. The risks of cardioversion in the sick $\frac{\rho}{\overline{0}}$ sinus syndrome are known (Lown, 1967). We used it with caution in 11 cases and there were no significant problems.

Almost one-third of our patients were given permanent pacemakers. That reflects the severity $\frac{\bar{c}}{\vec{D}}$ of the symptoms and the difficulty of control with $\stackrel{\mathbb{D}}{\circ}$ other therapy. Pacemakers eliminate bradyarrhythmias and have also been observed to diminish or even eliminate the tachyarrhythmias (Radford, and Julian, 1974; Cheng, 1968; Sigurd et al., 1973). Nevertheless, they have their own complications and the decision to commit a child to longterm cardiac pacing is a difficult one. Syncope is life-threatening and therefore an absolute indication for pacing.

The prognosis and natural history of the syndrome have not yet been determined. Symptoms have resolved with the development of permanent atrial fibrillation (Cohen, 1973; Stock, 1970; Radford and Julian, 1974). Interest has been shown recently in developing provocative tests to define the condition better (Mandel et al., 1972; Strauss et al., 1972; Gupta et al., 1974). Hopefully, these may help to predict which cases may prove the most severe. This should be particularly useful in cases resulting from cardiac surgery. With better understanding of the atrial conduction mechanisms of the sick sinus syndrome dysrhythmias after cardiac surgery may be avoided by changes in surgical technique. Meanwhile, the severity of symptoms and the potential risks must be weighed against the difficulties of the types of therapy available.

The purpose of this report of a retrospective survey of the clinical picture presented by children with ECG features of the sick sinus syndrome is to ensure general awareness of the condition and its problems in children. We are currently making prospective assessments of symptomatic and asymptomatic children to try to evaluate more precisely the physiological and pathological mechanisms of the sick sinus system, to determine the best treatment, and if possible, to discover how it may be prevented.

\section{REFERENCES}

Abella, J. B., Teisceira, O. H. P., Misra, K. P., and Hastreiter, A (1972). Changes of atrioventricular conduction with age in infants and children. American fournal of Cardiology, 30, 876. Blalock, A., and Hanlon, C. R. (1950). The surgical treatment of complete transposition of the aorta and the pulmonary artery. Surgery, Gynecology and Obstetrics, 90, 1.

Cheng, T. O. (1968). Transvenous pacing in the treatment of paroxysmal atrial tachyarrhythmias alternating with sinus 874 .

\section{,}


Chokshi, D. S., Mascarenhas, E., Samet, P., and Center, S. (1973). Treatment of sinoatrial rhythm disturbances with permanent cardiac pacing. American fournal of Cardiology, 32, 215.

Cohen, H. E. (1973). Sick sinus syndrome treatment. Circulation, 48, 671 .

Crook, B. R. M., Cashman, P. M. M., Stott, F. D., and Raftery, E. B. (1973). Tape monitoring of the electrocardiogram in ambulant patients with sinoatrial disease. British Heart Fournal, 35, 1009.

Easley, R. M., and Goldstein, S. (1971). Sino-atrial syncope. American fournal of Medicine, 50, 166.

Edwards, W. S., and Bargeron, L. M. (1965). More effective palliation of transposition of the great vessels. Fournal of Thoracic and Cardiovascular Surgery, 49, 790.

El-Said, G., Rosenberg, H. S., Mullins, C. E., Hallman, G. L., Cooley, D. A., and McNamara, D. G. (1972). Dysrhythmias after Mustard's operation for transposition of the great arteries. American fournal of Cardiology, 30, 526.

Ferrer, M. I. (1973). The sick sinus syndrome. Circulation, 47, 635.

Greenwood, R. D., Rosenthal, A., Sloss, L. J., Castaneda, A. R., and Nadas, A. S. (1974). Sick sinus syndrome after cardiac surgery in childhood. (Abst.) Circulation, Suppl. III, 49, 176.

Gupta, P..K., Lichstein, E., Chadda, K. D., and Badui, E. (1974) Appraisal of sinus node recovery time in patients with sick sinus syndrome. American fournal of Cardiology, 34, 265.

Hudson, R. E. B. (1967). Surgical pathology of the conducting system of the heart. British Heart fournal, 29, 646.

Isaacson, R., Titus, J. L., Merideth, J., Feldt, R. H., and McGoon, D. C. (1972). Apparent interruption of atrial conduction pathways after surgical repair of transposition of great arteries. American fournal of Cardiology, 30, 533.

Kaplan, B. M., Langendorf, R., Lev, M., and Pick, A. (1973). Tachycardia-bradycardia syndrome. American fournal of Cardiology, 31, 497.

Lloyd-Mostyn, R. H. Kidner, P. H, and Oram, S. (1973). Sinuatrial disorder including the brady-tachycardia syndrome. Quarterly Fournal of Medicine, 42, 41.

Lown, B. (1967). Electrical reversion of cardiac arrhythmias. British Heart fournal, 29, 469.

Mandel, W. J., Hayakawa, H., Allen, H. N., Danzig, R., and Kermaier, A. I. (1972). Assessment of sinus node function in patients with the sick sinus syndrome. Circulation, 46, 761.

Moss, A. J., and Davis, R. J. (1974). Brady-tachy syndrome. Progress in Cardiovascular Diseases, 14, 439.
Mulholland, H. C., Kidd, B. S. L., Trusler, G. A., and Mustard, W. T. (1975). Arrhythmias following the Mustard procedure for transposition of the great arteries. Programme and Abstracts. Canadian Cardiovascular Society. 28, 6.

Mustard, W. T., Keith, J. D., Trusler, G. A., Fowler, R., and Kidd, L. (1964). Surgical management of transposition of the great vessels. Fournal of Thoracic and Cardiovascular Surgery, 48, 953.

Nugent, E. W., Varghese, P. J., Pieroni, D. R., and Rowe, R. D. (1974). Sluggish sinus node syndrome as part of congenital heart disease. American fournal of Cardiology, 33, 160.

Radford, D. J., and Julian, D. G. (1974). Sick sinus syndrome: experience of a cardiac pacemaker clinic. British Medical Fournal, 3, 504.

Rasmussen, K. (1971). Chronic sinoatrial heart block. American Heart Fournal, 81, 38.

Rokseth, R., and Hatle, L. (1974). Prospective study in the occurrence and management of chronic sinoatrial disease with followup. British Heart fournal, 36, 582.

Rubenstein, J. J., Schulman, C. L., Yurchak, P. M., and DeSanctis, R. W. (1972). Clinical spectrum of the sick sinus syndrome. Circulation, 46, 5.

Scott, O., and Macartney, F. J. (1974). The sick sinus syndrome. (Abst.) Archives of Disease in Childhood, 49, 819.

Sigurd, B., Jensen, G., Meibom, J., and Sandoe, E. (1973). AdamsStokes syndrome caused by sinoatrial block. British Heart Fournal, 35, 1002.

Stock, J. P. P. (1970). Diagnosis and Treatment of Cardiac Arrhythmias, 2nd ed., p. 214. Butterworths, London.

Strauss, H. C., Saroff, A. L., Bigger, J. T., and Giardina, E. G. V. (1973). Premature atrial stimulation as a key to the understanding of sinoatrial conduction in man. Circulation, 47, 86.

Wan, S. H., Lee, G. S., and Toh, C. C. S. (1972). The sick sinus syndrome. A study of 15 cases. British Heart fournal, 34, 942.

Young, D. (1973). Later results of closure of secundum atrial septal defect in children. American fournal of Cardiology, 31, 14.

Correspondence to Dr. D. J. Radford, Department of Paediatrics, Division of Cardiology, Hospital for Sick Children, 555 University Avenue, Toronto, Ontario, Canada M5G 1 X8. 